\title{
ОСВОСННЯ СТУДЕНТАМИ ПРАКТИЧНИХ НАВИЧОК ПРИ КРЕДИТНО-МОДУЛЬНІЙ ОРГАНІЗАЦІЇ НАВЧАЛЬНОГО ПРОЦЕСУ: ПРОБЛЕМИ ТА ПОШУК ШЛЯХІВ ЇХ ВИРІШЕННЯ
}

\author{
Ю. В. Думанський, О. М. Талалаєнко, М. Б. Первак
}

Донецький національний медичний університет ім. М. Горького

\section{STUDENTS' MASTERING OF PRACTICAL SKILLS AT CREDIT- MODULAR SYSTEM AT DONETSK NATIONAL MEDICAL UNIVERSITY: PROBLEMS AND SEARCHING WAYS OF THEIR SOLUTION}

\author{
Yu. V. Dumanskyi, O. M. Talalayenko, M. B. Pervak \\ Donetsk National Medical University by M. Horkyi
}

\begin{abstract}
У статті проаналізовано ситуацію щодо навчання студентів практичних навичок при кредитно-модульній організації навчального процесу в Донецькому національному медичному університеті. Висвітлено проблеми, що склалися, та зазначено шляхи їх вирішення.
\end{abstract}

In the article the analysis of the situation regarding students' mastering of practical skills at credit-modular system implementation at Donetsk National Medical University was given. The problems were formulated and the ways of their solution were described.

Вступ. Відповідно до чинних державних стандартів вищої медичної освіти [3] головною метою навчання студентів у вищих медичних навчальних закладах (ВН3) є оволодіння випускником умінням працювати з пацієнтом: збирати скарги, анамнез захворювання та життя (у тому числі професійний), проводити фізикальне обстеження, призначати необхідні лабораторні та інструментальні дослідження і трактувати ї результати, встановлювати попередній клінічний діагноз та визначати тактику лікування хворого 3 певною патологією, діагностувати невідкладні стани та надавати при них екстрену медичну допомогу. Отже, основним об'єктом вивчення у медичному ВНЗ $\epsilon$ пацієнт. Реалізація такого навчання можлива лише в умовах медичного закладу - поліклініки або лікарні. Саме тому не існує заочної медичної освіти (принаймні на додипломному етапі) і підготовка лікарів не лише в Україні, але і в інших країнах світу за своєю організацією значно відрізняється від інших галузей освіти: технічної, гуманітарної тощо [5, 6]. Всі клінічні кафедри, навіть пропедевтичного рівня, розташовані на базілікувальних закладів (університетських клінік), тобто навчальний процес у медичних ВНЗ за своєю сугтю з самого початку є професійно-орієнтованим.
Для оволодіння студентом професійними компетенціями лікаря дуже важливим є освоєння ними практичних навичок.

Основна частина. У Донецькому національному медичному університеті ім. М. Горького в межах розробленої та реалізованої у ВНЗ оригінальної системи управління якістю підготовки фахівців $[1,2,4]$ ще на початку 80-х років минулого століття було створено наскрізну програму навчання практичним навичкам. Виходячи $з$ неї, визначили чітке коло практичних навичок для освоєння на кожній кафедрі, а також розробили та впровадили індивідуальні книжки практичних навичок, у яких викладачі кафедр та керівники практик реєстрували результати контролю освоєння практичних навичок кожним студентом. Але перш ніж контролювати, треба навчити студента їх виконувати. Саме тому в затвердженій у нашому ВН3 структурі практичного заняття не менш ніж $60 \%$ було відведено на самостійну роботу студента під керуванням викладача.

Останнім часом, після впровадження кредитно-модульної організації навчального процесу ситуація з навчанням студентів практичним навичкам, на жаль, погіршилась, особливо на молодших курсах. Це,

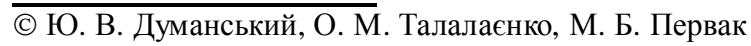


головним чином, пов’ язано з необхідністю за умови відсутності іспитів проводити щоденне оцінювання рівня знань-умінь кожного студента у великих групах (по 10-15 осіб). Поступово контроль став займати більшу частку в структурі практичних занять i вийшов ледь не на перше місце. Викладачі стали приділяти менше уваги навчанню студентів практичних навичок, інколи вважаючи, що під час заняття достатньо лише продемонструвати студенту правильне виконання тієї або іншої практичної навички, а потім наприкінці модуля лише перевірити рівень ії освоєння. Головне, на думку таких викладачів, добре підготувати студентів до підсумкового модульного контролю та ліцензійних тестових іспитів, а освоїти навички студенти можуть і позааудиторно, а також під час виробничої практики.

На жаль, остання також зазнала суттєвих змін при впровадженні кредитно-модульної організації навчального процесу. Так, на медичних факультетах виробнича практика II та III курсів (“Догляд за хворими” та "Сестринська практика") відповідно до навчальних планів проходить не літом, як раніше, а у межах семестру на клінічних кафедрах. Зрозуміло, що одночасне протягом 2-3 академічних годин перебування на одній базі декількох груп (у середньому - 40-50 осіб, інколи більше) значно погіршує роботу студентів 3 пацієнтами (особливо у невеликих відділеннях) і суттєво зменшує ймовірність освоєння практичних навичок (на відміну від традиційного проведення практики у багатьох медичних закладах влітку). Крім того прирівнювання цих двох практик до дисциплін “у сітці розкладу” зумовлює необхідність виставити кожному студенту оцінку за проведене заняття і підштовхує викладача під час аудиторних занять використовувати ситуаційні завдання або тести, на яких і проходить розбір “теоретичної частини” практики. Щодо практичних навичок, то студент під час аудиторної частини практики лише має можливість спостерігати за їх виконанням і у кращому випадку може один-два рази спробувати їх виконати сам. А безпосереднє освоєння практичних навичок знову залишається для позааудиторного етапу.

Краща ситуація з виробничою практикою IV та V курсів, яку проводять, як і раніше, влітку, але незрозуміле скорочення їі тривалості - на 33 \% на IV курсі (4 тижні замість 6) і на $20 \%$ на V курсі (4 тижні замість 5) - не сприяє підвищенню їх ефективності. Крім того, додатковою проблемою проведення цих практик $є$ необхідність розподіляти всіх студентів лише у лікувальні заклади Донецька через неможливість виконати вимоги фінансових органів щодо оплати всім студентам відрядних витрат. Це призводить до того, що у відділення одночасно приходить в 2-3 рази більше студентів, ніж при розподілі їх по всій області, а отже, звужує можливості студента самостійно освоїти та закріпити практичні навички.

Всі вищенаведені проблеми призвели до зниження рівня освоєння студентами практичних навичок, що було відзначено викладачами та завідувачами випускаючих клінічних кафедр, на які поточного навчального року вперше прийшли “вихованці” кредитномодульної організації навчального процесу.

Для зміни ситуації на краще керівництвом нашого університету було створено робочу групу, яку очолив перший проректор і до якої увійшли керівник галузевої науково-методичної лабораторії з питань додипломної підготовки лікарів та завідувачі випускаючих кафедр. Головним завданням цієї групи було визначено розробку заходів для поліпшення якості освоєння студентами практичних навичок.

Перш за все, було прийнято рішення поновити практику ведення книжок практичних навичок, забуту при впровадженні кредитно-модульної організації навчального процесу, щоб, по-перше, окреслити перед студентами коло необхідних практичних навичок, $\mathrm{i}$, по-друге, підвищити відповідальність кафедр і окремих викладачів за цей розділ роботи.

При підготовці оновленого варіанта книжок практичних навичок ми опиралися на чинні державні стандарти медичної освіти, в яких сформульовані кінцеві цілі підготовки у медичному ВН3, і тому зосередилися на суто медичних навичках, вилучивши навички, які набувають студенти на медико-біологічних кафедрах. У результаті було підготовлено 4 окремі книжки практичних навичок - для всіх медичних спеціальностей, за якими у нашому ВН3 проходить навчання на додипломному рівні. Зрозуміло, що найбільша кількість практичних навичок передбачена для студентів стоматологічного факультету. Кожна 3 цих книжок складається 33 розділів - таких, як: 1) наскрізна програма практичних навичок $з$ певної спеціальності, 2) облік освоєння практичних навичок на конкретних кафедрах, 3) облік освоєння практичних навичок під час виробничої практики (по курсах і профілях).

Потім всі зазначені у наскрізній програмі практичні навички було розподілено на дві групи: такі, що можуть бути освоєні лише при роботі з пацієнтом, і такі, які на першому етапі можуть бути освоєні при роботі 
з тренажерами, фантомами, муляжами, електронними моделями тощо. До речі, такі засоби навчання дуже широко використовуються у закордонних медичних ВНЗ, особливо у тих країнах, де доступ студента до пацієнта на додипломному етапі є обмеженим $[5,7,8]$.

Для підвищення рівня освоєння студентами другої групи практичних навичок керівництвом нашого університету було прийнято рішення про створення окремого Центру практичної підготовки, в якому студенти зможуть працювати як під час практичних занять $з$ певних дисциплін, так і позааудиторно. На сьогодні вже відремонтовано виділені приміщення та вирішено питання про закупівлю необхідних технічних засобів навчання, планується розклад роботи Центру та проходить відбір працівників для роботи у його штаті. Сподіваємося, що з першого вересня він вже відкриє свої двері для студентів.

\section{Лiтература}

1. Система безперервної медичної освіти / В. М. Казаков, О. М. Талалаєнко, М. Г. Гаріна, М. С. Каменецький. - Донецьк : Здоров'я, 1994. - 174 с.

2. Методологія і реалізація системи управління якістю медичної освіти / [В. М. Казаков, О. М. Талалаєнко, М. Г. Гаріна та ін.]. - Донецьк, 2001.-213 с.

3. Складові галузевих стандартів вищої освіти напряму підготовки 1101 "Медицина" освітньо-кваліфікаційного рівня “спеціаліст” за спеціальностями “Лікувальна справа”, “Педіатрія”, “Медико-профілактична справа”. - Київ : Міністерство освіти і науки України, 2003. - 369 с.

4. Управление качеством подготовки специалистов : программно-целевой подход (на примере высшего и послевузовского медицинского образования) / [В. Н. Казаков, Н. А. Селезнева, А. Н. Талалаенко и др.] -2-е изд. - Москва, 2007.-215c.
Вважаємо, що сприятимуть поліпшенню ситуації 3 освоєнням студентами практичних навичок і видані нашими викладачами навчальні посібники - “Збірник алгоритмів стоматологічних маніпуляцій”, “Лікарські маніпуляції” тощо.

Висновок. Вважаємо, що всі вищезазначені заходи, а саме: розробка наскрізної програми навчання практичним навичкам, впровадження індивідуальних книжок практичних навичок з обліком контролю освоєння студентом практичних навичок на певних кафедрах та під час певних виробничих практик, а також функціонування спеціального Центру практичної підготовки дозволять суттєво підвищити ефективність навчання студентів практичних навичок. Значною мірою поліпшенню ситуації сприятиме вирішення МОН та МO3 України питання про зменшення співвідношення викладач-студент у медичних ВН3 до 1/6.

5. Abstracts of Conference of Association for Medical Education in Europe. - Prague, 2008. - 330 p.

6. Dent J. A. A practical guide for medical teachers / I. A. Dent, R. M. Harden. - Churchill Livingstone Elsevier: Edinburgh, London, New York, Oxgord, Philadelphia, St.Louis, Sydney, Toronto, 2009. $-435 \mathrm{p}$.

7. Auscultation of the heart: a trial of classrom teaching versus computer-based independent learning / J. P. Finley, G. P. Sharratt, M. A. Nanton [et al.] // Med. Educ. - 1998. Vol. 32, № 4. - P. 357-361.

8. Acquisition of surgical skills: a randomized trial of didactic, videotape and computer-based training / A. N. Summers, G. C. Rinehart, D. Simpson, P. N. Redlich // Surgery. - 1999.Vol. 126(2). -P.330-336. 